\title{
Saudi Arabia Joined WTO Opportunity or Threat to Saudi Corporations
}

\author{
Dr. Shaza Wasfi Ezzi \\ Colage of Economic \& Management Abdelaziz King \\ University
}




\section{Preface}

The main idea underlying this research project was that globalization has ushered a new stage in the history of world civilization, and that people, wherever they are, are affected by its dynamics whether they are willing or hesitant partners. Along with this, it is recognized that while Human Resource Development, as an activity, has been significantly affected by globalization everywhere, but, as a discipline or a field of study, it has fallen short of giving globalization the attention it deserves compared with what is given to it by other disciplines such as economics or political sciences. This faltering in attention or concern is particularly evidenced in the Arab region, where globalization is frequently mentioned as a target, but rarely dealt with as a phenomenon that requires serious examination. Hence this research project is focusing on globalization and its impact on Human Resource Development.

The purpose of this research is to present a well defined and detailed plan to develop and restructure the HR applied on medium and large size Saudi corporations. The conclusion we reached to, was satisfactory to serve the purpose of this research project. At the end, we concluded that the banking and industrial sectors are the most influential sectors in driving the economy. Consequently, studying the HR development in these two sectors will have great impact in the Saudi economy in general and the private sector in particular. 


\section{المستخلص}

يقدم هذا البحث خطـة كاملـة ومفصلة لتطوير و إعـادة هيكلـة الموارد البشـرية ، وسـيتم

التطبيق على بعض الثـركات السعودية المتوسطة و الكبيرة الحجم ـ حيث يقوم البحث بتطوير نموذج لقياس أداء ومدى كفاءة الموارد البشرية والذى سيتم تطبيقه كدر اسة ميدانية بالتطبيق على الشركة السعودية لصناعة مستلزمات السجاد "Mattex" كثركة صناعية ، و على عينة من قطاع البنوك متمثلة فى " بنكك سـامبا " و " بنلك السـودية الفرنسى " كمؤسسـات ماليـة ، على أسـاس أن هذان القطاعان هما الأكثر تأثثراً فى الاقتصاد السعودى ـ وستكون مخرجات ونتائج هذا البحث بمثابـة مرجـع يمكـن للثـركات السـعودية الأخـرى الاسترشـاد بـهـ وتطبيـق نفس الاسـتر اتيجية المستخدمة فى هذا البحث كخطة لتطوير المـوارد البشرية لديهم ـ وتعتبر الفائدة العظمى مـن تطوير هيكل الموارد البشرية للشركات السعودية بناءاً على المعـيير العالميـة ، أنها ستكون حتمـا فرصة ذهبية للشركات السعودية نتيجة للانضمام لمنظمة التجارة العالمية ، وليس تهديداً لها .

إن الهدف الأساسـى في التركيز على القبام بدر اسـة وتحليـل الثـركات المستهدفة محل الدر اسة هو لإثبات أن الثـركات المحليـة التى تستثمر فى بنيـة الموارد البشـرية وتقوم بالاعتمـاد عليها كمؤشر استر اتيجى ، فإنها بإمكانها أن تواجه المنافسة وخاصة من الثركات الدوليـة القادمـة للسوق السعودى طبقا لقو اعد انضمام السـودية إلى منظمـة التجـارة العالميـة ــ لذلك فـإن الدراسـة ستبدأ بتطوير أداة تقيبم لمدى تطبيق الموارد البشرية للقطاعين محل التطبيق ، و التى سيتبعها تحليل لدر اسة الحالتين لتقييم مدى تطبيق أفضل استخدام للموارد البشرية والذى سيقوم - بإذن الله

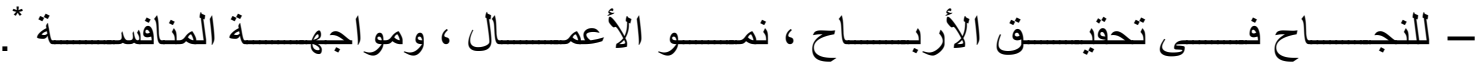




\begin{abstract}
The current research presents well defined and detailed plan to develop and restructure the Human resource (HR) applied on medium and large size Saudi corporations. A standard HR model will be developed in this research with specific application to the Saudi company for the manufacture of carpets "Mattex" as a representative company for the industrial sector and on a sample of the banking sector in the form of the "Samba Bank" and "the Saudi French Bank" as financial institutions, on the basis that these are the most influential sectors in the Saudi economy, as field study. Other Saudi companies can apply the same strategy used in this research to implement HR development plan in their own companies. Once the HR structure is developed based on the world class standards, the accession to the World Trade Organization (WTO) will definitely be considered as an excellent opportunity to the Saudi companies, not a threat.

The scope focus on conducting study and analysis for the targeted companies to prove that the local companies who invest in HR infrastructure and consider it as a strategic direction can face the competition especially from international companies. The study will start by developing an assessment instrument for implementing the HR best practices of the selected companies and then a through business situational analysis will be conducted to assess that implementing HR best practices will lead for success in terms of profitability, business growth and competition.
\end{abstract}




\section{Table of Contents}

\begin{tabular}{|l|l|l|}
\hline & Title Page & \\
\hline & Pbstract & \\
\hline & Table of Contents & \\
\hline & List of Figures & \\
\hline & List of Tables & \\
\hline 1 & Introduction & \\
\hline & 1.1 Statement of the Problem & \\
\hline & 1.2 Relevant General Background & \\
\hline & 1.3 Literature Review & \\
\hline & 1.5 Rationale for Topic Selection & \\
\hline & 1.6 Research Objectives & \\
\hline & 1.7 Research Hypotheses & \\
\hline & 1.8 Scope & \\
\hline & 1.9 Limitations of the Study & \\
\hline 2 & Materials and Methods & \\
\hline & 2.1 Phase & \\
\hline & 2.2 Phase & \\
\hline & 2.3 Phase & \\
\hline 3 & Results & \\
\hline & 3.1 Descriptive Data Analysis of The Banking Sector & \\
\hline & 3.2 Descriptive Data Analysis of The Industrial Sector. & \\
\hline 4 & Discussion and Hypotheses Testing & \\
\hline & 4.1 Discussions and Analysis of the "Enablers & \\
\hline & 4.2 Discussions and Analysis of the "Enablers" & \\
\hline 5 & Obstacles & \\
\hline 6 & Conclusions and Recommendations & \\
\hline 7 & References & \\
\hline & Arabic abstract & \\
\hline
\end{tabular}

\section{List of Figures}

Figure $1:$ The CAF Model

Figure 2: The Research Framework 


\section{Lest of Tables}

\begin{tabular}{|l|l|l|}
\hline Table 1 & $:$ Descriptive Analysis of The Banking Sector & \\
\hline Table 2 & $:$ Descriptive Analysis of The Industrial Sector & \\
\hline Table 3 & $\begin{array}{l}: \text { Summary of the Descriptive Analysis of Banking and } \\
\text { Industrial sectors }\end{array}$ & \\
\hline Table 4 & $:$ Descriptive Analysis of HR Management & \\
\hline Table 5 & $:$ The Descriptive Analysis of The Partnership Criterion & \\
\hline Table 6 & $:$ The Descriptive Analysis of The Leadership Criterion & \\
\hline Table 7 & $:$ The Descriptive Analysis of the Employees Criterion & \\
\hline Table 8 & $\begin{array}{l}: \text { The Descriptive Analysis of the Customer, Society, and } \\
\text { Performance criteria. }\end{array}$ & \\
\hline
\end{tabular}




\section{Introduction}

\subsection{Statement of the Problem}

World Trade Organization (WTO) General Council formally concluded on 11 November 2005 negotiations with Saudi Arabia on the terms of the country's membership to the WTO. Saudi Arabia became the $149^{\text {th }}$ full WTO Member on 11 December 2005. It is the world's 13th largest merchandise exporter and the 23rd largest importer.

This event will create a new economic environment within the Kingdom. All Saudi corporations should be prepared to face this new situation. The Saudi corporations will face a sever competitions from similar world corporations, which have started already invading the Saudi market to sell their products and services. This can be considered as a real "threat "to the Saudi corporations. On the other hand, the Saudi corporations may consider this event as a golden "opportunity "to sell and market their products and services not only to the invading world corporations but also to all other countries in the world. In addition, Saudi corporations can partner with the world corporations before and after they enter the Saudi market.

The most valuable asset and resource of any organization is the "Human Resource" (HR). Therefore, in order for the Saudi corporations to take advantage, cope, and maximize their benefits from this event, they should focus on developing their HR based on the best practices and enterprise models applied worldwide.

\subsection{Relevant General Background}

Generally speaking, joining the WTO has many advantages and disadvantages. Most of the countries that joined the WTO have modified their policies to maximize their benefits from the new affiliation and 
minimize their losses, if any due to this partnership. The reactions vary from one country to another depending on the culture, economic status, social constrains, and many other factors.

Despite tremendous wealth from oil production, Saudi Arabia is considered a developing economy based on per capita GDP. As a member of the World Trade Organization since 2005, the long-protected Saudi economy is now facing international competition. Therefore, we focus our attention in this research on the current status of the Saudi organizations. Joining the WTO will open the doors to the world organizations to establish their businesses in the KSA to take advantage of the strong Saudi economy for years to come.

In this research, we demonstrate the frame of analyzing the enablers and the results of the factors that govern and influence the improvement of the Saudi organization to be able to stand the sever competition that is expected to happen as a result of KSA joining the WTO.

The detailed analyses and the recommendations at the end of this research project will help to draw the road map for the Saudi organizations to capitalize on their strengths and develop plans to minimize the impact of the weaknesses.

\subsection{Importance of the Study}

This research project will draw the road map for the Saudi organizations to apply and implement the best practices in the HR development to be able to face competition from the international organizations coming to the Saudi market as a result of the Saudi Arabia accession to the WTO. This research 
project describes how the Saudi organizations can translate their business strategy into individual and organizational standards.

The utilization of this research project can be summarized in the following points:

a. Draw the attention and convince the Saudi organizations to the importance of developing the HR based on the best practices.

b. Guide the organizations to the step by step methodology to measure the quality of the HR system they currently have.

c. Improve all HR elements, such as the recruitment, training, promotion, and competencies development, based on standard framework.

d. Standardize the processes of HR system development.

\subsection{Literature Review}

The human resources of an organization represent one of its largest investments. Human resource functions are tasks and duties human resource managers perform in both large and small organizations (e.g. determining the organization's human resource needs; recruiting, selecting, developing, counseling, and rewarding employees; acting as liaison with unions and government organizations; and handling other matters of employee well-being) to provide for and coordinate human resources (Byars and Rue, 2006, p4).

Human resource management (HRM) is a basic pillar of successful quality management. Schemerhom (2001) defined HRM as the "Process of attracting, developing, and maintaining a talented and energetic workforce 
to support organizational mission, objectives and strategies". Furthermore, Venkateshwara (2006) highlighted that labor is one of the most important factors contributing to organization's growth. To be successful in a global market, organizations need a highly motivated, skilled and satisfied workforce that are perform and rewarded sufficiently to both remain in the organization and be productive at low costs (Holt, 1993; Tichy et al., 1981). Therefore, many HR functions have been undergoing unprecedented changes in the last few years. New HR visions are being formulated, innovative HR strategies implemented a advanced HR information systems installed, HR structures redesigned, and HR processes reengineered (Yeung, 1996). Moreover, to add higher value to many organizations, many HR functions are being driven to lower HR costs, enhance the quality of HR services and find stronger linkages with business needs (Schuler, 1990; Yeung et al. 1994; Yeung \& Brockbank, 1995).

As HR is a part of the total management system in any organization, regardless of sector, size, structure or maturity, organizations need to establish an appropriate management system to be successful. The Excellence Model is a practical tool to help organizations to do this by measuring where they are on the path to Excellence; helping them understand the gaps; and then stimulating solutions. The Common Assessment Framework (CAF) is a tool for organizational self-assessment. It has been developed under the authority of the Directors-General of Public Administration of the EU member states in order to support the introduction of the idea and the principles of Total Quality Management (TQM) across the EU and beyond. A pilot version was presented in May 2000 and a first revised version was launched in 2002 (CAF Resource 
Centre, 2006). The CAF (see figure 1) is designed to be an easy-to-use tool for quality management allowing public organizations to identify their strengths and their areas for improvement, and paving the way for application of the fundamental concepts of quality. It is non prescriptive and does not involve strictly following a set of rules or standards, but provides a broad and coherent set of assumptions about what is required for a good organization and its management. Each organization can use it in its own way to manage and develop improvement, under the control of those who use the methods rather than an external evaluator. The use of the Common Assessment Framework is free, and it is open to all types of public sector organizations in all countries (CAP Resource Centre at the European Institute of Public Administration, 2005).

The CAP has been developed by exploiting the concepts, models and experiences of the "European Excellence Model" promoted by the European Foundation of Quality Management (EFQM), various national quality management tools derived from the Excellence Model and the Spryer Quality Award Scheme widely used in German-speaking European countries. The EFQM in short, was set up in 1988 by 14 large European organizations. Their objective was to achieve a permanent excellence in the European economy and they strived for a world in which the European organizations would be recognized as being excellent no matter where in the world (EFQM, 2003). The EFQM-Excellence model can be seen as a framework to measure progress in excellence. Excellence is defined by the EFQM-Excellence model as excellent managing of the organization and achieving results. In other words, the EFQM Excellence Model is a self assessment framework for measuring the overall quality to highlight the 
strengths and areas for improvement of an organization across all of its activities (HR is one of these activities). It looks at the organization from different angels at the same time (CAP Resource Centre, 2006). The Model focuses on what an organization does, or could do, to provide an excellent service or product to its customers, service users or stakeholders (http://www.proveandimprove.org).

The CAP is offered to use quality management techniques to improve performance and provides a self-assessment framework that is conceptually similar to the major TQM models, EFQM in particular, but is specially conceived for the public sector organizations, taking into account their differences. In contrast to the EFQM, it is less demanding and less systematic and therefore suitable for organizations at the starting point of the implementation of TQM. Moreover, compared to a fully developed Total Quality Management model, the CAF is a" light" model, suitable especially to get an initial impression of how the organization performs. It is assumed that any organization that intends to go further will select one of the more detailed models (such as the Speyer or EFQM models). The CAF has the advantage of being compatible with these models and may therefore be a first step for an organization wishing to go further with quality management (The Common Assessment framework CAF, 2002; CAF Resource Centre, 2006). Furthermore, Promberger et al., (2004); highlighted that using the CAF provides an organization with a powerful framework to initiate a process of continuous improvement. One of the aims of the CAF is therefore, to serve as a bridge between different quality management instruments and quality management cultures in Europe. It is 
not in competition with these instruments, but tries to complement them and to bring together their most important elements.

CAF is based on the nine criteria of the EFQM model and the Speyer model, which together form a logical and holistic framework and allow an assessment of all the relevant activities and actions and the performance of a public sector organization. For more details, the model is subdivided in 9 criteria. Every criterion is further split up in different sub-criteria, which deal with a particular aspect in detail (Schreurs, 2007). Five of these are grouped under 'Enablers' (leadership, policy and strategy, human resources management, partnerships and resources, and processes and change management) and four are 'Results' (people results, customer results, society results and key performance results). The 'Enablers' criteria cover what an organization does. The 'Results' criteria cover what an organization achieves. 'Results' are caused by 'Enablers' and 'Enablers' are improved using feedback from 'Results' (CAF Resource Centre, 2006). It is then possible to develop and implement improvement plans that deliver sustainable growth and enhanced performance for the organization. The criteria evaluated by the Common Assessment Framework are illustrated in the figure below: 


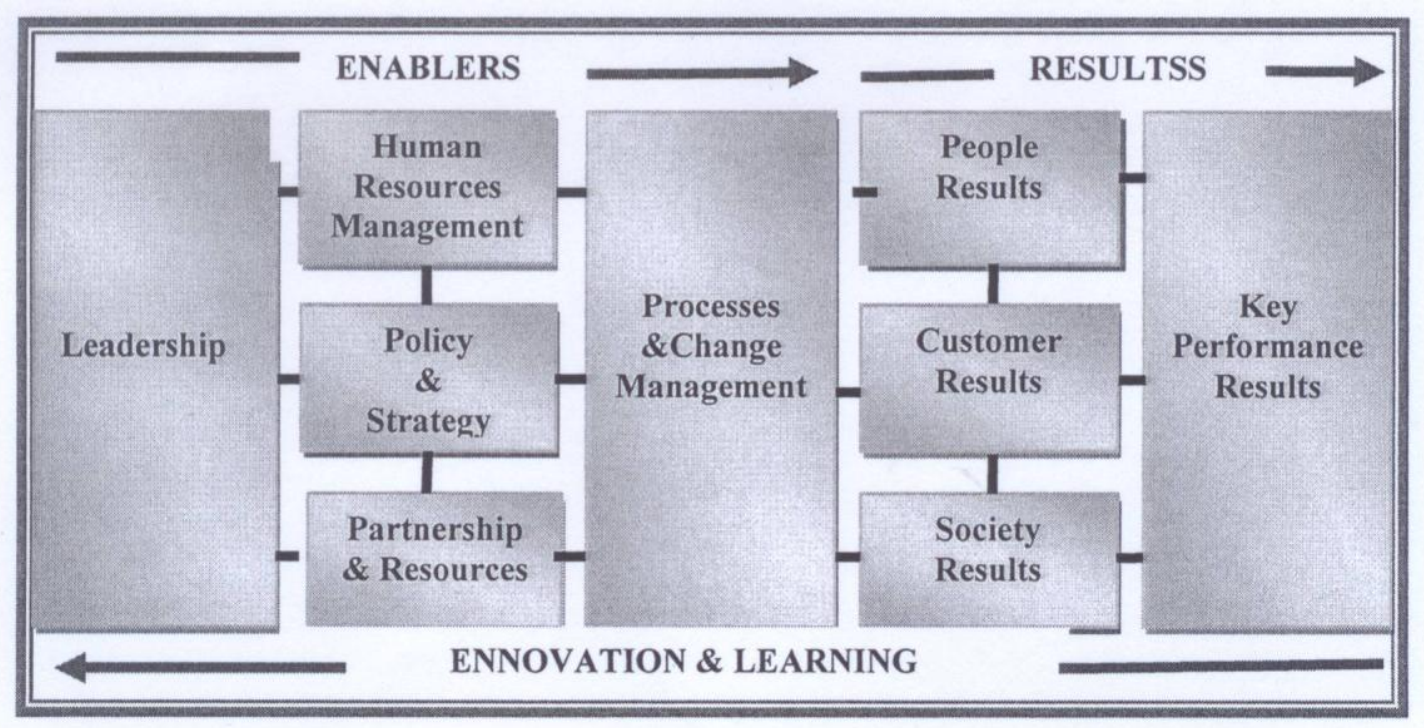

The Excellence models such as CAP and EFQM model has been widely adopted by thousands of

Figure 1: The CAP Model (Source: The Common Assessment Framework CAF, 2002)

Bottom, 2002; Sheffield Hallam University, 2003; Hides et al., 2004; Calvo-Mora et al., 2006; Tari 2008) to improve quality in higher education institutions. Also, EFQM model has been used as a framework for selfevaluation for e-learning quality management (Schreurs, 2006"; Deepwell, 2007). In relation to health care performance, massive researches have been conducted using total quality management (TQM) models such as CAF and EFQM model (e.g. Nabitz et al., 2000; Moeller, 2001; Sanchez, et al., 2006, Minkman, 2007). Maintaining and improving high quality in world tourism was the subject of many researches (e.g. Camison, 1996; Go and Covers, 2000). In addition, the excellence models have been used as a guide to TQM implementation by a large number of organizations (e.g. McCarthy et al., 2002; Samuelsson and Nilsson, 2002; Kaynak, 2003; 
Westerveld, 2003; McCarthy and Greatbanks, 2006; Santos-Vijande and Alvarez-Gonzalez, 2007; Bou-Llusar, 2008).

Geraedts et al. (2001 (and Schreurs (2007) highlighted the benefits of implementing a Work Performance Measurement System:

- Increase productivity and accuracy; Quite often, the fact that employees know that they are being measured will yield an improvement itself.

- Lower Turnover; once the system is in place sproblems are identified quickly and resolved.

- Better labor planning \& scheduling; With tighter specifications on what the workforce is able to do, planning hours for work content will result in fewer occurrences of overtime while meeting customer requirements.

- Decrease cycle time; Work will be completed in a shorter time frame using the same or less resources.

- Enabling the organization to identify its strengths and areas for improvement.

Some organizations undertake the Self-Assessment CAF model to measure and improve the overall quality of the organization, others for a department or operational unit. As we mentioned earlier the current research is focusing on the Human Resources as the most valuable asset and resource of any organization, in purpose to provide empirical evidence on the relationship between HR management practices and measures of organization performance based on the Common Assessment Framework (CAF) Excellence Model.

Accordingly, the research model has been modified (see Figure 2) based on the literature review and the preliminary interviews that were conducted 
with two human resources managers from banking sector and industrial sector. The research framework will be based on the original model (CAF model) with its nine criteria as Bou-Llusar et al. (2008) stressed that the CAF model should be considered as complete set criteria and the complete inter-correlations between them. The only modification in the research framework will be in the "Processes \& Change Management" criterion that will be focusing on the FIR activities. Processes as asserted by Philips (2004) lie at the heart of the CAF Excellence Model. The purpose of this tool is to enable the total management and FIR management to measure the quality of FIR processes. Secondly, to stimulate a continuous improvement program on the basis of "Plan, Do, Check, and Act" (Deming, 1982) to support the FIR functions within the company on the journey towards FIR Excellence.

Based on Deming (1982), the starting point usually should be planning. Therefore, "Processes \& Change Management" criterion will include (HR Planning ). According to Byars and Rue (2006), human resource planning (FIRP) is "a process of determining the human resource needs of an organization and ensuring that the organization has the right number of qualified people in the right jobs at the right time". To use this tool effectively, the organization should follow the human resource process (the modified criterion in the current research model) which is a way of recruiting and selecting people to the organization (Recruitment) ' getting them into jobs, seeing that they perform and are rewarded sufficiently Training \& Development (to both remain in the organization and be productive. Yoon and Suh (2003) showed that satisfied employees are more likely to work harder and provide better services via organizational 
citizenship behaviors. Employees who are satisfied with their jobs tend to be more involved in their employing organizations, and more dedicated to delivering services with a high level of quality. In addition, loyal employees are more eager to and more capable of delivering a higher level of service quality (Loveman, 1998). The composition of the management of human resource in the formation scientifically, technically and intellectually and culturally integrated and compatible with the requirements of the times (Organizational Development) and based on the variables and techniques, and provide access to the continuous development of those human resources and enable them to view the performance and participation and decision-making, including making them able and willing to actively participate in the activation of distinct plans and programs of the Secretariat and achieve its objectives (Organizational Culture Development).

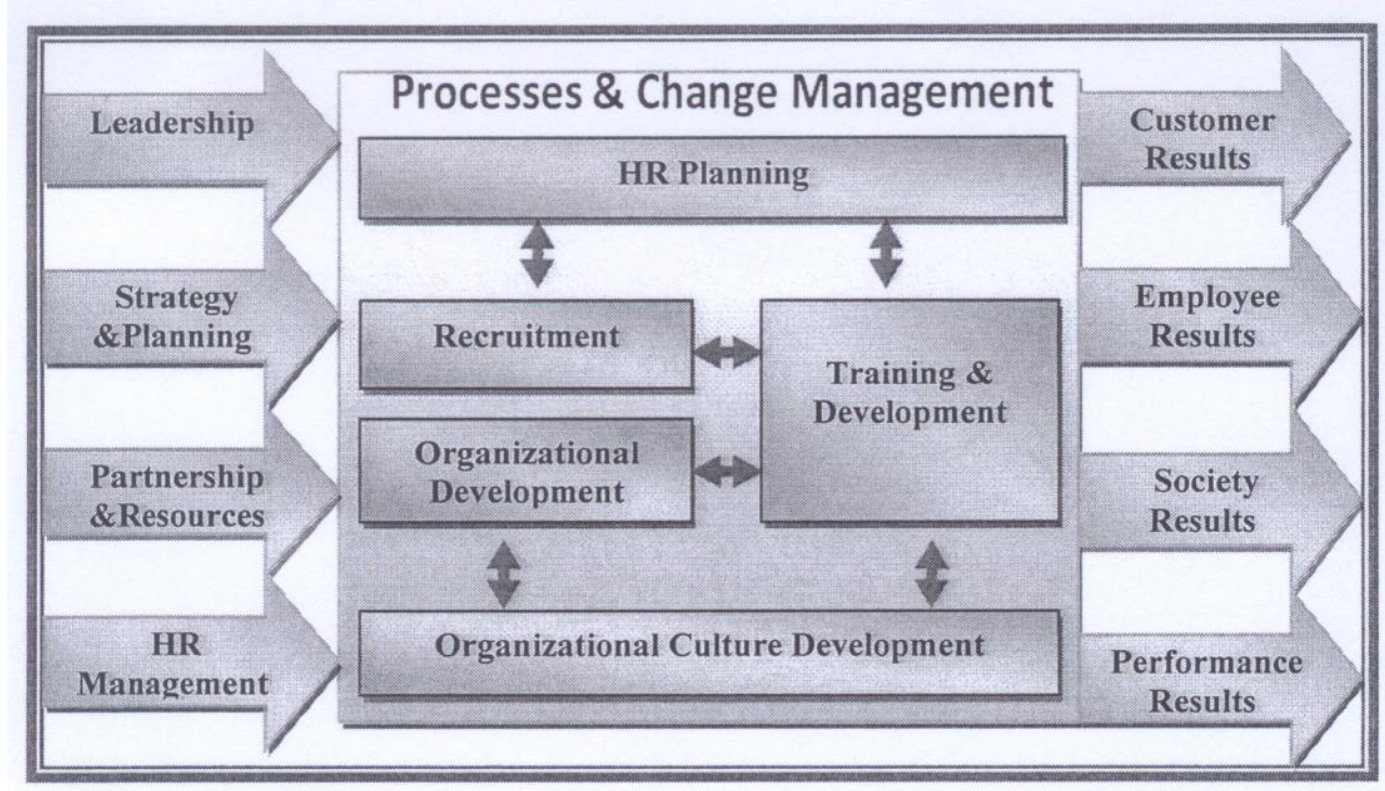

Figure 2 : The Research Framework 


\subsection{Rationale for Topic Selection}

The topic of KSA joining the WTO will have great impact on the Saudi economy. Foreign investments will increase bringing in the necessary funds for giant projects and businesses as the country's laws and regulations begin to conform to international standards. There should be an overall strategy for the KSA to face this new era and capitalize on the benefits of joining the WTO. On the other hand, there could be some negative aspects to this affiliation that need to be analyzed at this stage before it is late and the reaction will not be in time. It can be an excellent opportunity for the Saudi organizations to be prepared for this global new concept to cope with this trend.

\subsection{Research Objectives}

The research is focusing on how the medium and large size organizations can implement the HR best practices, which is the most important mechanism to drive high productivity and the quality of the products and services provided to face the competition of the well-structured foreign organization coming to the Saudi Market.

The objectives of this research project can be summarized in the following points :

a. Introduce the concept of the Human Resources development among Saudi Corporation.

b. Identify the methods and procedures that can be used to improve and enhance the productivity and quality of the Human Resources,

c. Develop the enterprise model of the Human Resources that can be implemented and customized for each specific organization. 
d. Establish a road map to close the gap between the current situation of the existing HR and the best practice HR model,

e. Draw an implementation plan in using the competencies in the training plan and recruitment plan,

f. Present the mechanism that can be used to monitor and control the HR progress.

g. Evaluate the various causes of the HR challenges .

\subsection{Research Hypotheses}

Based on the literature review on the total quality management which suggest, the quality culture practices may impact on business performance (Powell, 1995; Hendricks and Singhal, 2001; Terziovski et al., 2003; Vijande, 2007), HRM has a direct impact on the process management that may improve quality (Samson and Terziovski, 1999), employee satisfaction improves service quality (Flynn, 2005; Gustafsson, 2005), direct relationship between employee satisfaction and customer satisfaction (Barsade, 2002), the following hypotheses are formulated:

H1. Leadership is positively related to processes and change management. H2. Strategy and planning is positively related to processes and change management.

H3. Partnership and resources is positively related to processes and change management.

H4. Human resource management is positively related to processes and change management. 
H5. The processes of the human resource management is positively related to the customer satisfaction.

H6. The processes of the human resource management is positively related to the employee satisfaction.

H7. The processes of the human resource management is positively related to the organization performance.

\subsection{Scope}

The research is focusing on how the medium and large size Saudi organizations can implement the HR best practices, which is the most important mechanism to drive high productivity and the quality of the products and services provided to face the competition of the wellstructured foreign organization coming to the Saudi Market.

This research project will draw the road map for the Saudi corporations to apply and implement the best practices in the HR development to be able to face competition from the international corporations coming to the Saudi market as a result of the Saudi Arabia accession to the WTO. This research project describes how the Saudi corporations can translate their business strategy into individual and organizational standards.

The scope can be summarized as follows:

1. Develop the HR Enterprise Model based on the best practices.

- Explain the different frameworks used in HR modeling.

- Focus on the Common Assessment Framework (CAF) as the selected model for the research project.

- Characterize the possible element in the selected HR model. 
2. Hold preliminary interviews with the candidate corporations.

- Explain the importance of the HR development and its impact on the general performance of any corporation.

- Listen to the inputs from the selected corporations to the challenge they face in the HR area.

- Gather all possible information as far as the current structure of the HR.

3. Arrange for interviews to present the HR Model and the outcomes of the preliminary to HR specialists audiences from different sectors of the Saudi market.

- Formulate the HR model of the current situation in the sample corporations.

- Agree on the target HR model.

4. Develop the road map to migrate the HR situation in a specific corporation from the AS-IS to the TO-BE status.

- Draw the components of the current HR model

- Establish the desired HR model.

- Specify the migration steps of the current HR to the desired model.

As representatives to the Saudi organizations, we selected the following two sectors to perform the * study and analyses.

- Banking sector; and

- Industrial sector

There are two reasons we selected these two sectors to represent the Saudi economic sectors: 
1. The competition from the international corporations coming to the Saudi market will be more sever in these two sectors.

2. The success of these two sectors will drastically influence the other Saudi economic sectors due to the fact that these two sectors have larger influence and relationship to many other sectors.

\subsection{Limitations of the Study}

It is important to critically evaluate the results and the whole study. The present study has certain limitations that need to be taken into account when considering the study and its contributions. However, some of these limitations can be seen as fruitful avenues for future research under the same theme.

This study has focused on a phenomenon that is a very extensive and major one, i.e. the readiness of the Saudi organizations to compete and face the challenges in the globalization environment. Clearly, this represents a challenging task for research regardless of the more specific interests that the study may have. In this study, this extensive and complex phenomenon has been studied from a rather narrow empirical perspective. The selection of the single case study design naturally brings forth many limitations as far as the generalization of the results of the study is concerned. Thus, the empirical setting, the Saudi organizations and the situation they are facing as a result of the WTO, can only be seen as a kind of pilot context of the globalization process. On the other hand, this also represents the whole idea of making a case study. By understanding something about this particular case more in depth, we might eventually also learn something about more general phenomena. The empirical analysis of markets conducted in this study represents therefore only a single case and what is more, from the 
perspective of this single actor. To study the impact of the globalization phenomenon in general and the WTO in particular, through multiple case study design, for example, is clearly one of the future research challenges in this topic. Multiple case study design would enable us to test the conceptual framework of the study further. However, as the theme of this study has been related to WTO and its impact on the Saudi originations, it can of course be seen that eventually the globalization is likely to derive more studies, even through multiple case studies becomes different, i.e. the emergence needs to be studied retrospective.

The chosen case sectors also can be seen to include certain limitations in the sense that there are so many other sectors in the Saudi market that need to be treated differently. Although this was used as a selection criterion, it could also be argued that for the future research on this topic, an empirical setting where the market had advanced a bit further would have revealed more, especially as far as the dynamism of the market process and development of market is concerned. Particularly the presented typology for the Saudi market markets can be criticized on in terms of the limitation to two sectors only. However, the presented typology does not merely rely on the economic sector but rather, the methodology and analyses developed in this research study forms an essential foundation and can be generalized to all other sectors regardless of their specialty. However, the typology needs further research involving broader sectors. However, the decision to concentrate on the analysis of two sector cases especially from the perspective of the influence on other sectors was essential in order to tackle the complexity of the definition of Saudi economic sectors. 
The case selection also presented some limitations in terms of the actual numbers of organizations in each sector that were studied. As it turned out, there were some problems in employing one or two organization from each sector and therefore the sample organization may not fully represent the full sector. However, this does not present any significance problem in this study due to the fact that the each organization is considered as a test bed for applying the research methodology that could be generalize to larger number of organizations.

It can be argued, that the fact that some modifications were needed to the model used and/or the questionnaire together the information. All in all, the model developed for this research study and the questionnaire that has been extracted to reflect all the components of the model, are just a method to collect as much information as possible about the attributes of the performance of the organizations in general.

Another limitation of this study is the perspective adopted. Instead of trying to understand the Saudi market sectors in general, this study has been first and foremost limited to the development and the application of the model that could be generalized to other sectors in a wider scope.

\section{Materials and Methods}

The research project is divided into three phases:

\subsection{Phase 1}

This phase will include the following steps:

- Market segmentation.

- Selecting samples of the organizations.

- Designing the questionnaire to include all research criteria. 
- Distributing and collecting the information based on the questionnaire.

- Documenting the gathered information.

In order to gather information about the Saudi organizations to analyze and draw the conclusions and recommendation regarding the Human Resource (HR) Development, we decided to look at the Saudi private market in general. Then we segmented this market into several sectors. We concluded that the most influential sectors in the Saudi economy are:

- Banking sector; and

- Industrial sector

Accordingly, we randomly selected two out of the eleven banks in Saudi Arabia as our sample for the banking sector that representing $\% 20$ of the total. At the same time, we randomly selected a manufacturing organization from the industrial sector as a case study. Basically, a case study is an in depth study of a particular situation rather than a sweeping statistical survey (Zikmund, 1997). It is a method used to narrow down a very broad field of research into one easily researchable topic. Whilst it will not answer a question completely, it will give some indications and allow further elaboration and hypothesis creation on a subject.

We developed the questionnaire (Appendix 1) and started collecting the required information based on the HR Enterprise Model as shown in Figure 1 and 2.

The questionnaire is divided into nine major criteria. Each one of these criteria is divided into few sub-criteria. Under each sub-criterion, there are several questions to cover all elements of the HR Model. 
We distributed copies of the questionnaire to the selected organizations of the above two sectors. We had different methods to distribute and collect the required information such as:

- E-mail communication

- Fax the questionnaire and collect the completed ones either by fax or by hand.

- Phone calls to fill the required information while both parties have copy of the questionnaire.

\subsection{Phase 2}

This phase will include the following steps: $f$

- Tabulating and analyzing the gathered information.

- Discuss the results obtained with senior HR managers to be able analyze the indications and the attributes of the results based on HR professional individuals.

- Commenting on the feedback and inputs from the HR senior managers.

After gathering and tabulating the results collected from the designated organizations (detailed in section 3), the research team shared the information with three senior HR managers in other organizations. The comments and observations of those HR managers are documented, analyzed, and discussed in the result section.

\subsection{Phase 3}

Draw the conclusions and recommendations of the research project from the previous discussions, analysis, and comments. 
An implementation plan has been developed to achieve the objectives of the research. The plan can be summarized in the following steps:

1. Develop the HR Enterprise Model based on the best practices:

- Explain the different frameworks used in HR modeling.

- Focus on the Common Assessment Framework (CAF) as the selected model for the research project (Figure 1).

- Characterize the possible element in the selected HR model

2. Hold preliminary interviews with the candidate corporations:

- Explain the importance of the HR development and its impact on the general performance of any corporation.

- Listen to the inputs from the selected corporations to the challenge they face in the HR area.

- Gather all possible information as far as the current structure of the HR.

3. Arrange for workshops to present the HR Model and the outcomes of the preliminary interviews to audiences from different sectors of the market:

- Formulate the HR model of the current situation in the sample organization (Figure 2).

- Agree on the target HR model.

- Develop the road map to close the gap between current and future HR models.

4. Develop the road map to migrate the HR situation in a specific corporation from the AS-IS to the TO-BE status.

- Draw the components of the current HR model

- Establish the desired HR model.

- Specify the migration steps of the current HR to the desired model. 


\section{Results}

This section will include the results obtained during the term of the project and data analysis

\subsection{Descriptive Data Analysis of The Banking Sector}

This section addresses descriptive analysis for the nine criteria that been used to measure the overall quality in general and the quality of HR processes in particular.

The questionnaire employed a six-point Likert scale to evaluate the 'Enablers' criteria with "0" representing "No evidence or only anecdotal evidence of an approach", "1" representing "An approach is planned (plan)", "2" representing "An approach is planned and implemented (Do)", "3" representing "An approach is planned, implemented and reviewed (Check)", "4" representing "An approach is planned, implemented and reviewed on the basis of benchmarking data and adjusted accordingly (Act)", "5" representing "An approach is planned, implemented, reviewed on the basis of benchmarking data, adjusted and fully integrated into the organization".

With regard to evaluate the 'Results' criteria, the questionnaire also employed a six-point Likert scale but, with "0" representing "No results are measured", "1" representing "Key results are measured and show negative or stable trends", "2" representing "Results show modest progress", "3" representing "Results show substantial progress", "4" representing "Excellent results are achieved and positive comparisons to own targets are made", "5" representing "Results are achieved, positive comparisons to 
own targets are made and positive benchmarks against relevant organizations are made".

Table 1 shows the averages of the two banks to the nine criteria. All the average scores for the nine criteria were above the scale mid-point of (2.5). The first five criteria that represent the 'Enablers' criteria (Leadership, Strategic planning, HR management, Partnership \& Resources, and Processes \& change management), which cover what an organization does, the average values for these five criteria were varying between "HR Management" that scored the lowest average value (3.75) and "Strategic \& Planning" that scored the highest average (4.08). The second set of criteria (Customer, Employees, Society, and Performance) represents the 'Results' criteria that cover what an organization achieves. The average scores for these criteria were varying between the "Employees" criteria that scored the lowest average (3.6) and the "Customer" criteria that scored the highest (3.85).

Based on the Banking Sector analysis :

1. "Leadership" consists of three sub-criteria with an overall average score of (4.0) for the two banks. The sub-criteria 1.2 "Develop and implement a system for managing the organization" scored the highest average score of (4.4). This indicates that the banks have already prepared working plans and activated the implementation of these plans. In addition, these plans have been compared with other knowledge bases and improved. Since the score is higher than 4.0, this indicates that the 1.2 sub-criteria have partially been compared with information of similar banks and have been corrected for improvements. In addition, these sub-criteria have 
been incorporated in the organization systems. The conclusion is that the revision and the improvement of the bank's system became continuous process and happen on regular basis.

2. "Strategic \& Planning" consists of two sub-criteria with an overall average score of (4.08). Average value of the two sub-criteria were very similar to each other which was around (4.0). This indicates that the banks have already prepared working plans and activated the implementation of these plans. In addition, these plans have been compared with other knowledge bases and improved.

3. "HR Management" consists of three sub-criteria and the score is (3.75) as an overall average. The average value for each subcriterion was varying between (3.5) and (3.9). The sub-criteria 3.3 "Involve employees by developing dialogue and empowerment" scored the lowest average value (3.5), while the rest of sub-criteria 3.1 "Plan, manage and improve human resources with regard to strategy and planning", and 3.2 "Identify, develop and use competencies of the employees aligning individual, team and organizational targets and goals" scored almost the same average value (3.85) and (3.9). In fact, the average values showed quite big difference between the two banks. While Samba bank indicates to a high scores for the three sub-criteria (4.5) and above, the Saudi French bank indicates much lower scores than the other bank especially for the 3.3 criteria that scored lower than the mid-point (2.3). Similarly, for the other two sub-criteria 3.1 and 3.2 scored average values (3.2) and (3.1) respectively, which were also much lower than the other bank. This indicates that in relation to HRM 
which reflects how the organization manages, develops and releases the knowledge and full potential of its people at individual, team-based and organization-wide levels; and plans these activities in order to support its policy and strategy and the effective operation of its people, these activities still have deficiencies in the performance that needs to be developed.

4. "Partnership \& Resources" consists of four sub-criteria represented score (3.8) as an overall average. The average value for each subcriteria were varying between (3.6) and (4.15). The sub-criteria 4.4 "Manages technology" scored the highest average value (4.15), which indicate that the banks strive to improve operational efficiency by efficient use of technology. In addition, the banks know how to coordinate its strategies with its technological equipment and machinery. The rest of sub-criteria 4.1 "Develops and implements key partnership relations", 4.2 "Develops and implements partnerships with the citizens/customers" and 4.3 "Manages knowledge" were very similar to each other between (3.6) and (3.75). This result indicates that banks trying to be prepared to form alliances with partners and collaborators in the market in an attempt to achieve competitive advantage. But actually, they still need to work harder to be able to compete under the sever competitions from similar world corporations.

5. "Processes \& Change Management" consists of two sub-criteria represented score (3.08) as an overall average. The average value for each sub-criteria were varying between (3.6) and (4.0). As "Processes" lie at the heart of the CAP Excellence Model as we 
mentioned earlier. The purpose of this tool is to enable the total management and HR management in particular to measure the quality of management processes. The score result shows that the banking sector in general still needs a lot to do to improve its processes and change management. In all cases, an organization should be able to identify the key processes, which it performs in order to deliver its expected outputs and outcomes.

The second set of criteria represents the 'Results' criteria that cover what an organization achieves, and those results are caused by the 'Enablers'.

6. "Customer" consists of two sub-criteria represented score (3.85) as an overall average. The average value for both sub-criteria were very close between (3.8) and (3.9). This indicates that the banks are achieving good results in relation to the satisfaction of their internal and external customers. The banks have achieved in their efforts to meet the needs and expectations of customers and citizens.

7. "Employees" consists of two sub-criteria represented score (3.6) as an overall average which is actually the lowest average value of the nine criteria. Average value for both sub-criteria were (3.6). This relatively low score indicates that the banks did not achieve high in relation to the satisfaction of their people. This indicates that the people motivation measurements are not high.

8. "Society" consists of two sub-criteria represented score (3.75) as an overall average. Average value for both sub-criteria were varying between (3.6) for the first sub criterion 8.1 "Results of societal 
performance" and (3.9) for the 8.2 "Results of environmental performance". This indicates that the banks are achieving reasonable results in satisfying the needs and the expectations of the local, national, and international community. This includes the perception of the banks' approach to quality of life.

9. "Performance" consists of two sub-criteria represented score (3.7) as an overall average. The average value for both sub-criteria were varying between (3.65) for the first sub-criterion 9.1 "Goal achievement" and (3.8) for the 9.2 "Financial performance". This indicates that banks have achieved good financial results and they could partially reach their objectives.

\begin{tabular}{|c|c|c|l|c|c|c|c|}
\hline \multicolumn{2}{|c|}{ Table 1: Descriptive Analysis of The Banking Sector } \\
\hline No & Criteria & \multicolumn{2}{|c|}{ Sub-Criteria } & $\begin{array}{c}\text { No. } \\
\text { of } \\
\text { items }\end{array}$ & $\begin{array}{c}\text { Samba } \\
\text { Bank }\end{array}$ & $\begin{array}{c}\text { Saudi } \\
\text { French } \\
\text { Bank }\end{array}$ & Average \\
\hline \multirow{2}{*}{1} & 1.1 & $\begin{array}{l}\text { Give a direction to the } \\
\text { organization: develop } \\
\text { and communicate } \\
\text { vision, mission and } \\
\text { values }\end{array}$ & 5 & 3.4 & 3.8 & 3.6 \\
\cline { 2 - 8 } & 1.2 & $\begin{array}{l}\text { Develop and } \\
\text { implement a system for } \\
\text { managing the } \\
\text { organization }\end{array}$ & 6 & 3.8 & 5 & 4.4 \\
\cline { 2 - 8 } & 1.3 & $\begin{array}{l}\text { Motivate and support } \\
\text { the people in the } \\
\text { organization and act as } \\
\text { a role model }\end{array}$ & 7 & 4.3 & 3.7 & 4 \\
\hline
\end{tabular}




\begin{tabular}{|c|c|c|c|c|c|c|c|}
\hline \multirow{2}{*}{2} & \multirow{2}{*}{$\begin{array}{c}\text { Strategic \& } \\
\text { Planning }\end{array}$} & 2.1 & $\begin{array}{l}\text { Develop, review and } \\
\text { update strategy and } \\
\text { planning }\end{array}$ & 6 & 4.5 & 3.8 & 4.15 \\
\hline & & 2.2 & $\begin{array}{l}\text { Implement strategy } \\
\text { and planning in the } \\
\text { whole organization }\end{array}$ & 5 & 4.4 & 3.6 & 4 \\
\hline & $\begin{array}{c}\text { Total } \\
\text { Average }\end{array}$ & & & & 4.45 & 3.7 & 4.08 \\
\hline \multirow{4}{*}{3} & \multirow{3}{*}{$\begin{array}{c}\text { HR } \\
\text { Management }\end{array}$} & 3.1 & $\begin{array}{l}\text { Plan, manage and } \\
\text { improve human } \\
\text { resources with regard } \\
\text { to strategy and } \\
\text { planning }\end{array}$ & 9 & 4.5 & 3.2 & 3.85 \\
\hline & & 3.2 & $\begin{array}{l}\text { Identify, develop and } \\
\text { use competencies of } \\
\text { the employees aligning } \\
\text { individual, team and } \\
\text { organizational targets } \\
\text { and goals }\end{array}$ & 8 & 4.62 & 3.1 & 3.9 \\
\hline & & 3.3 & $\begin{array}{l}\text { Involve employees by } \\
\text { developing dialogue } \\
\text { and empowerment }\end{array}$ & 6 & 4.66 & 2.3 & 3.5 \\
\hline & $\begin{array}{c}\text { Total } \\
\text { Average }\end{array}$ & & & & 4.6 & 2.9 & 3.75 \\
\hline \multirow[t]{2}{*}{4} & \multirow{2}{*}{$\begin{array}{l}\text { Partnership } \\
\text { \& Resources }\end{array}$} & 4.1 & $\begin{array}{l}\text { Develops and } \\
\text { implements key } \\
\text { partnership relations }\end{array}$ & 6 & 4 & 3.2 & 3.6 \\
\hline & & 4.2 & $\begin{array}{l}\text { Develops and } \\
\text { implements } \\
\text { partnerships with the } \\
\text { citizens/customers }\end{array}$ & 5 & 3.6 & 3.6 & 3.6 \\
\hline
\end{tabular}




\begin{tabular}{|c|c|c|c|c|c|c|c|}
\hline & & 4.3 & Manages knowledge & 6 & 3.5 & 4 & 3.75 \\
\hline & & 4.4 & Manages technology & 3 & 4.4 & 3.9 & 4.15 \\
\hline & $\begin{array}{c}\text { Total } \\
\text { Average }\end{array}$ & & & & 3.9 & 3.7 & 3.8 \\
\hline \multirow[t]{3}{*}{5} & \multirow{2}{*}{$\begin{array}{c}\text { Processes \& } \\
\text { Change } \\
\text { Management }\end{array}$} & 5.1 & $\begin{array}{l}\text { Identifies, designs, } \\
\text { manages and improves } \\
\text { processes }\end{array}$ & 6 & 3.8 & 3.34 & 3.6 \\
\hline & & 5.2 & $\begin{array}{l}\text { Plans and manages } \\
\text { modernization and } \\
\text { innovation }\end{array}$ & 6 & 4.2 & 3.8 & 4 \\
\hline & $\begin{array}{c}\text { Total } \\
\text { Average }\end{array}$ & & & & 4 & 3.57 & 3.8 \\
\hline \multirow[t]{3}{*}{6} & \multirow[t]{2}{*}{ Customer } & 6.1 & $\begin{array}{l}\text { Results of } \\
\text { customer/citizen } \\
\text { satisfaction } \\
\text { measurements }\end{array}$ & 7 & 3.8 & 4 & 3.9 \\
\hline & & 6.2 & $\begin{array}{l}\text { Indicators of } \\
\text { customer/citizen- } \\
\text { oriented } \\
\text { measurements }\end{array}$ & 3 & 3.3 & 4.3 & 3.8 \\
\hline & $\begin{array}{c}\text { Total } \\
\text { Average }\end{array}$ & & & & 3.5 & 4.15 & 3.85 \\
\hline \multirow[t]{3}{*}{7} & \multirow[t]{2}{*}{ Employees } & 7.1 & $\begin{array}{l}\text { Results of people } \\
\text { satisfaction and } \\
\text { motivation } \\
\text { measurements }\end{array}$ & 6 & 3.7 & 3.5 & 3.6 \\
\hline & & 7.2 & $\begin{array}{l}\text { Indicators of people } \\
\text { results }\end{array}$ & 4 & 3.25 & 4 & 3.6 \\
\hline & $\begin{array}{c}\text { Total } \\
\text { Average }\end{array}$ & & & & 3.5 & 3.75 & 3.6 \\
\hline
\end{tabular}




\begin{tabular}{|c|c|c|c|c|c|c|c|}
\hline \multirow[t]{2}{*}{8} & \multirow[b]{2}{*}{ Society } & 8.1 & $\begin{array}{l}\text { Results of societal } \\
\text { performance }\end{array}$ & 10 & 3.5 & 3.7 & 3.6 \\
\hline & & 8.2 & $\begin{array}{l}\text { Results of } \\
\text { environmental } \\
\text { performance }\end{array}$ & 8 & 3.5 & 4.3 & 3.9 \\
\hline & $\begin{array}{c}\text { Total } \\
\text { Average } \\
\end{array}$ & & & & 3.5 & 4 & 3.75 \\
\hline \multirow[t]{3}{*}{9} & \multirow[t]{2}{*}{ Performance } & 9.1 & Goal achievement & 7 & 3.57 & 4 & 3.8 \\
\hline & & 9.2 & Financial performance & 6 & 3.7 & 3.6 & 3.65 \\
\hline & $\begin{array}{c}\text { Total } \\
\text { Average }\end{array}$ & & & & 3.6 & 3.8 & 3.7 \\
\hline
\end{tabular}

\subsection{Descriptive Data Analysis of The Industrial Sector}

Table 2 shows the descriptive analysis of the industrial company to the nine criteria. The analysis of this sector will be based on a case study analysis. Analyzing results for a case study tends to be more opinion based than statistical methods. The usual idea is to try and collate data into a manageable form and construct a narrative around it. The researcher shows some numerical data to judge only trends and not analyze every last piece of data. In addition, unlike a scientific study which deals with facts, the case study is based on opinion and is very much designed to provoke reasoned debate. There is no right or wrong answer in a case study (http://www.experiment-resources.com).

Table 2 shows that all the average scores for the items that included in the nine criteria were above the scale mid-point of 2.5. The first five criteria that represent the 'Enablers' criteria which cover what an organization does, the average values for these five criteria were varying between "HR 
Management" that scored the lowest average value (2.67) and "Strategic \& Planning" that scored the highest average (4.5). The second set of criteria represents the 'Results' criteria that cover what an organization achieves. The average scores for these criteria were varying between the "Employee" criteria that scored the lowest average (3.25) and the "Society" criteria that scored the highest (4.0).

Based on the results of the industrial company and the average for each criterion, we can draw the following general observations and analysis:

1. "Leadership" consists of three sub-criteria with an overall average score of (4.34). The two sub-criteria 1.1 "Give a direction to the organization: develop and communicate vision, mission and values" and 1.2 "Develop and implement a system for managing the organization" scored the highest average score of (5.0) for each of them. This indicates that the company has already prepared working plans and activated the implementation of these plans. In addition, these plans have been compared with other knowledge bases and improved. However, the subcriterion 1.3 "Motivate and support the people in the organization and act as a role model" scored (3.0) which indicates that the company has shortage in regard to motivating the employees. Since the overall score is higher than 4.0, this indicates that the 1.1 and 1.2 sub-criterion have been compared with information of similar organizations and have been corrected for improvements. In addition, these sub-criterion have been incorporated in the organization. The conclusion is that the revision and the improvement became continuous process and happen on regular basis. 
2. "Strategic \& Planning" consists of two sub-criterion with an overall average score of (4.5). The sub-criterion 2.1 "Develop, review and update strategy and planning" scored (4.0), this indicates that the company has already prepared working plans and activated the implementation of these plans. The sub-criterion 2.2 "Implement strategy and planning in the whole organization" scored (5.0), this indicates in addition, to preparing the plans and implementing it, these plans have been compared with other knowledge bases and improved.

3. "HR Management" consists of three sub-criteria represented score (2.67) as an overall average, which is actually the lowest average value of the nine criteria. The average value for the first two sub-criteria 3.1 "Plan, manage and improve human resources with regard to strategy and planning" and 3.2 "Identify, develop and use competencies of the employees aligning individual, team and organizational targets and goals" was (3.0) for both of them, while the third sub-criteria 3.3 "Involve employees by developing dialogue and empowerment" was lower than the mid-point (2.0). This indicates that the company has a plan for the HR and the plan has been implemented. The reason the score of 3.3 sub criterion was low because the implemented plan was never reviewed.

4. "Partnership \& Resources" consists of four sub-criteria represented score (3.25) as an overall average. The average value for each sub-criterion were varying between (2.0) and (5.0). The sub-criteria 4.3 "Manages knowledge" scored the highest average value (5.0), which indicate that the company is prepared to form alliances with partners and collaborators in the market in an attempt to achieve competitive 
advantage. The sub-criterion 4.4 "Manages technology" scored (4.0) which shows that the company strives to improve operational efficiency by efficient use of technology. The rest of sub-criteria 4.1 "Develops and implements key partnership relations", 4.2 "Develops and implements partnerships with the citizens/customers" both of them scored (2.0). This indicates that the company still needs to a lot with improving the review of its implanted plan for the partnership \& resources.

5. "Processes \& Change Management" consists of two sub-criteria represented score (4.0) as an overall average. The average value for each sub-criterion was (4.0). This indicates that the company is striving to manage, improve, and develop its processes in order to innovate and support its strategy and planning to satisfy their customers and stakeholders. Since the score of this criterion "Processes \& Change Management" is considerably high, this indicates that the company has implemented a plan this criterion. In addition, this plan has been reviewed on the basis of benchmarking data and adjusted accordingly. There is still a shortage in this criterion due to the fact that it has not been fully integrated into the company.

The second set of criteria represents the 'Results' criteria that cover what an organization achieves and they are caused by 'Enablers'.

6. "Customer" consists of two sub-criteria represented score (3.75) as an overall average. The average value for the first sub-criterion 6.1 "Results of customer/citizen satisfaction measurements" was (3.5) and the 6.2 "Indicators of customer/citizen-oriented measurements" scored (4.0). This score indicates that is achieving well in relation to the 
satisfaction of its internal and external customers. The organization has a plan to achieve the customer satisfaction and directly measure its satisfaction. This plan has been implemented and reviewed. Partially, the implemented plan has been reviewed on the basis of benchmarking data and adjusted accordingly. The plan is not fully integrated into the organization.

7. "Employees" consists of two sub-criteria represented score (3.25) as an overall average. Average value for the first sub-criteria 7.1 "Results of people satisfaction and motivation measurements" was (3.0) and the 7.2 "Indicators of people results" was (3.5). These results show that the company has achieved noticeable improvement with regard to the employee satisfaction. This actually match with the "HR Management" criteria that achieved very similar score.

8. "Society" consists of two sub-criteria represented score (4.0) as an overall average. Both sub-criteria were scored (4.0). This indicates that the banks have achieved good results with a positive comparison with respect to their objectives in regard to the social and the external environment responsibilities.

9. "Performance" consists of two sub-criteria represented score (3.85) as an overall average. The average value for the first sub-criteria 9.1 "Goal achievement" was (3.7) and 9.2 "Financial performance" was (4.0). This indicates that the company shows substantial progress with regard to goals achievement, and they could partially reach their objectives. 


\begin{tabular}{|c|c|c|c|c|c|c|}
\hline No & Criteria & & Sub-Criteria & $\begin{array}{l}\text { No. of } \\
\text { items }\end{array}$ & score & Average \\
\hline & & 1.1 & $\begin{array}{l}\text { Give a direction to the } \\
\text { organization: develop and } \\
\text { communicate vision, } \\
\text { mission and values }\end{array}$ & 5 & 5 & \\
\hline & Leadership & 1.2 & $\begin{array}{l}\text { Develop and implement a } \\
\text { system for managing the } \\
\text { organization }\end{array}$ & 6 & 5 & 4.34 \\
\hline & & 1.3 & $\begin{array}{l}\text { Motivate and support the } \\
\text { people in the organization } \\
\text { and act as a role model }\end{array}$ & 7 & 3 & \\
\hline & Strategic \& & 2.1 & $\begin{array}{l}\text { Develop, review and update } \\
\text { strategy and planning }\end{array}$ & 6 & 4 & \\
\hline 2 & Planning & 2.2 & $\begin{array}{l}\text { Implement strategy and } \\
\text { planning in the whole } \\
\text { organization }\end{array}$ & 5 & 5 & 4.5 \\
\hline \multirow{3}{*}{3} & \multirow{3}{*}{$\begin{array}{l}\text { HR } \\
\text { Management }\end{array}$} & 3.1 & $\begin{array}{l}\text { Plan, manage and improve } \\
\text { human resources with } \\
\text { regard to strategy and } \\
\text { planning }\end{array}$ & 9 & 3 & \multirow{3}{*}{2.67} \\
\hline & & 3.2 & $\begin{array}{l}\text { Identify, develop and use } \\
\text { competencies of the } \\
\text { employees aligning } \\
\text { individual, team and } \\
\text { organizational targets and } \\
\text { goals }\end{array}$ & 8 & 3 & \\
\hline & & 3.3 & $\begin{array}{l}\text { Involve employees by } \\
\text { developing dialogue and } \\
\text { empowerment }\end{array}$ & 6 & 2 & \\
\hline
\end{tabular}




\begin{tabular}{|c|c|c|c|c|c|c|}
\hline \multirow{4}{*}{4} & \multirow{4}{*}{$\begin{array}{l}\text { Partnership } \\
\& \\
\text { Resources }\end{array}$} & 4.1 & $\begin{array}{l}\text { Develops and implements } \\
\text { key partnership relations }\end{array}$ & 6 & 2 & \multirow[b]{2}{*}{3.25} \\
\hline & & 4.2 & $\begin{array}{l}\text { Develops and implements } \\
\text { partnerships with the } \\
\text { citizens/customers }\end{array}$ & 5 & 2 & \\
\hline & & 4.3 & Manages knowledge & 6 & 5 & \multirow{4}{*}{4} \\
\hline & & 4.4 & Manages technology & 3 & 4 & \\
\hline \multirow[b]{2}{*}{5} & \multirow{2}{*}{$\begin{array}{l}\text { Processes \& } \\
\text { Change } \\
\text { Management }\end{array}$} & 5.1 & $\begin{array}{l}\text { Identifies, designs, manages } \\
\text { and improves processes }\end{array}$ & 6 & 4 & \\
\hline & & 5.2 & $\begin{array}{l}\text { Plans and manages } \\
\text { modernization and } \\
\text { innovation }\end{array}$ & 6 & 4 & \\
\hline \multirow[b]{2}{*}{6} & \multirow{2}{*}{ Customer } & 6.1 & $\begin{array}{l}\text { Results of customer/citizen } \\
\text { satisfaction measurements }\end{array}$ & 7 & 3.5 & \multirow[b]{2}{*}{3.75} \\
\hline & & 6.2 & $\begin{array}{l}\text { Indicators of } \\
\text { customer/citizen-oriented } \\
\text { measurements }\end{array}$ & 3 & 4 & \\
\hline \multirow[t]{2}{*}{7} & \multirow[t]{2}{*}{ Employees } & 7.1 & $\begin{array}{l}\text { Results of people satisfaction } \\
\text { and motivation } \\
\text { measurements }\end{array}$ & 6 & 3 & \multirow[t]{2}{*}{3.25} \\
\hline & & 7.2 & Indicators of people results & 4 & 3.5 & \\
\hline \multirow{2}{*}{8} & \multirow{2}{*}{ Society } & 8.1 & $\begin{array}{l}\text { Results of societal } \\
\text { performance }\end{array}$ & 10 & 4 & \multirow{2}{*}{4} \\
\hline & & 8.2 & $\begin{array}{l}\text { Results of environmental } \\
\text { performance }\end{array}$ & 8 & 4 & \\
\hline \multirow{2}{*}{9} & \multirow{2}{*}{ Performance } & 9.1 & Goal achievement & 7 & 3.7 & \multirow{2}{*}{3.85} \\
\hline & & 9.2 & Financial performance & 6 & 4 & \\
\hline
\end{tabular}




\section{Discussion and Hypotheses Testing}

In this section, we will analyze the consolidated results of the two sectors; the banking sector and the industrial sector as a representation of the "Saudi organization".

In order to enrich the research results and develop the road map to close the gap between current and future HR models, a workshop has been held and a number of the HR specialists have been invited to seek their comments, feedback, and their assessment to this research project in general and the results obtained from the two sectors in particular. Their views will be presented during the discussion of the results.

The following table 3 combines the nine criteria and the results of each sector as well as the average to represent a Saudi organization.

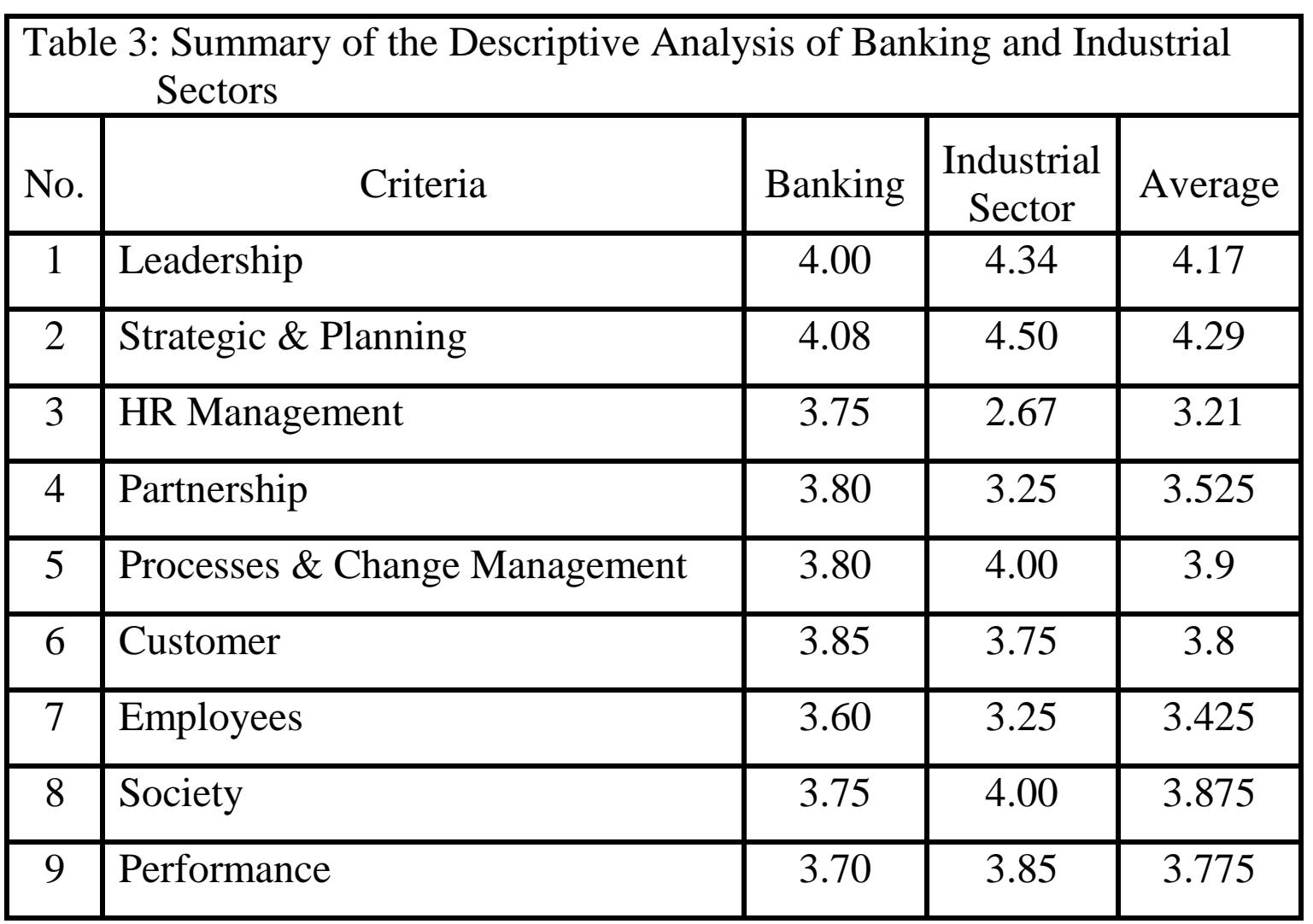


The right column of table 3 represents the average of the nine criteria for the selected sample of the chosen two sectors. In the following we will discuss firstly the "Enablers" and secondly the "Results".

\subsection{Discussions and Analysis of the "Enablers"}

The "Enablers" that represent criteria from 1 to 5 will be analyzed based on DEMING Cycle that includes Plan, Do, Check, Act.

Doing further analysis to understand the percentage of success of each criterion individually we take them one by one:

- Leadership: The score of 4.17 represents $4.17 / 5.00=83.4 \%$ of the full integration of the planning, implementation, review on the basis o benchmarking data, and adjustment.

- Strategic \& Planning: The score of 4.29 represents $4.29 / 5.00=$ $85.8 \%$ of meeting the above standard.

- HR management: The score of 3.21 represents 3.21/5.00 $=64.2 \%$ of meeting the above standard.

- Partnership: The score of 3.525 represents 3.525/5.00 $=70.5 \%$ of meeting the above standard.

- Processes \& Change Management: The score of 3.9 represents $3.9 / 5.0=78 \%$ of meeting the above standard.

As a conclusion from the above analysis, the "HR management" scored the lowest among the other five criteria. This result requires further analysis on these criteria in particular to understand the weakest points in the "subcriteria" that lowered the score of the HR. The following table focuses only on the details of the HR sub-criteria for in-depth further analysis. 


\begin{tabular}{|c|l|c|c|c|}
\hline \multicolumn{3}{|c|}{ Table 4 : Bescriptive Analysis of HR Management } \\
\hline No. & \multicolumn{1}{|c|}{ Criteria } & $\begin{array}{r}\text { Banking } \\
\text { Sector }\end{array}$ & $\begin{array}{c}\text { Industrial } \\
\text { Sector }\end{array}$ & Average \\
\hline 3.1 & $\begin{array}{l}\text { Plan, manage and improve human } \\
\text { resources with regard to strategy } \\
\text { and planning }\end{array}$ & 3.85 & 3 & 3.425 \\
\hline 3.2 & $\begin{array}{l}\text { Identify, develop and use } \\
\text { competencies of the employees } \\
\text { aligning individual, team and } \\
\text { organizational targets and goals }\end{array}$ & 3.9 & 3 & 3.45 \\
\hline 3.3 & $\begin{array}{l}\text { Involve employees by developing } \\
\text { dialogue and empowerment }\end{array}$ & 3.5 & 2 & 2.75 \\
\hline
\end{tabular}

It is obvious from the table above that the weakest criterion that drove the score of the HR Management down was in criterion 3.3. The indication is that organizations, particularly industrial, do not get the employees involved by developing dialogue and empowerment. In addition, they do not tend to use the method of involving employees in the development of plans and strategies. Executives do not seek agreement between managers and employees on goals and on ways of measuring goal achievement. This point has been stressed by one of the professional HR in the workshop and he strongly recommended that the target group must be directly involved in the process to make use of their own knowledge and experiences.

To get more in depth looking for areas of weaknesses, we created the following table for both sectors that presents the "Partnership" criterion, which highlights how the organization plans and manages its partnerships 
and internal resources in order to support its policy and strategy and the effective operation of its processes.

\begin{tabular}{|c|l|c|c|c|}
\hline \multicolumn{5}{|c|}{ Table 5 : Bescriptive Analysis of the Partnership Criterion } \\
\hline No. & \multicolumn{1}{|c|}{ Sub-Criterion } & $\begin{array}{c}\text { Banking } \\
\text { Sector }\end{array}$ & $\begin{array}{c}\text { Industrial } \\
\text { Sector }\end{array}$ & Average \\
\hline 4.1 & $\begin{array}{l}\text { Develops and implements key partnership } \\
\text { relations }\end{array}$ & 3.6 & 2 & 2.8 \\
\hline 4.2 & $\begin{array}{l}\text { Develops and implements partnerships with the } \\
\text { citizens/customers }\end{array}$ & 3.6 & 2 & 2.8 \\
\hline 4.3 & Manages knowledge & 3.75 & 5 & 4.375 \\
\hline 4.4 & Manages technology & 4.15 & 4 & 4.75 \\
\hline
\end{tabular}

The first two sub-criteria under the enabler "Partnership" scored the lowest scores for the both sectors. These two sub-criteria scored very low (2.0) for the industrial sector due to the fact that the industrial organization does not pay much attention and consideration to develop and implement partnership relations in general and with the citizens/customers in particular. For example it does not pay that much attention to establishing appropriate partnership agreements taking into account the nature of the relationship. Also, it does not define the responsibilities in managing the partnerships or regularly monitoring and evaluating the processes, the results and the nature of partnerships. In addition to neither training employees to allow them to work effectively with partners nor exchanging staff with partners to develop and implement the partnership relations. On the other hand, the sub-criteria "Manage Knowledge" scored (5.0) which means the organization pay the full attention to develop systems for managing, keeping and assessing knowledge in the organization and share it with partners. Also, executives should ensure that all employees have 
access to the knowledge relevant to their tasks and objectives. Developing internal channels to spread information throughout the whole organization such as Internet and newsletters, is a key success factor to communicate and interconnect employees across the organization. In addition, implementing an integrated policy of technologies in accordance with the strategic and operational objectives will enhance the communication channels across the organization.

In addition, one of the HR specialist pointed out that "the gap between Saudi Organizations and International standards, and here I specify in the industrial organizations according to my experience is very large, caused by many reasons, the involvement of people, beginning by owners or top management, the structures are flat, four levels in companies and six levels in large multinational groups and this from the owner or CEO to the simple worker or operator, no need for positions without added value, participation of all the members of the organization without exception and differentiation, exchange of ideas and acceptance of propositions, non exclusion of lower levels participation in the strategy, the indicators are important and most of the time very indicative of the situation, the management of issues is factual and by the GEMBA process, go on field, communication is very important in both senses ascendant and descendant, more autonomy and personnel participation".

In fact this comment is very much consistent with the results obtained from the survey. Involve employees by developing dialogue, communication, and empowerment is a key factor in any organization's success. Yet, the score is very low in the results of these two sectors. That is what the HR 
specialist is referring to as the major difference between Saudi organizations and European organizations.

Further details support the weakness of the HRM, when we look deeply on the first criterion which is the "Leadership" that presented in the following table we will find that the third sub-criteria scored the lowest (3.0) in the industrial organization, these sub-criteria related to "motivate and support the people in the organization and act as role model". This result support the conclusion of the weakness of the HRM in general from the point of view of the shortage of demonstrating personal willingness to change by accepting constructive feedback and suggestions for improving the personal leadership style.

\begin{tabular}{|c|l|c|c|c|}
\hline \multicolumn{6}{|c|}{ Table 6 : The Descriptive Analysis of The Leadership Criterion } \\
\hline No. & \multicolumn{1}{|c|}{ Sub-Criterion } & $\begin{array}{c}\text { Banking } \\
\text { Sector }\end{array}$ & $\begin{array}{c}\text { Industrial } \\
\text { Sector }\end{array}$ & Average \\
\hline 1.1 & $\begin{array}{l}\text { Give a direction to the organization: } \\
\text { develop and communicate vision, } \\
\text { mission and values }\end{array}$ & 3.6 & 5 & 4.3 \\
\hline 1.2 & $\begin{array}{l}\text { Develop and implement a system } \\
\text { for managing the organization }\end{array}$ & 4.4 & 5 & 4.7 \\
\hline 1.3 & $\begin{array}{l}\text { Motivate and support the people in } \\
\text { the organization and act as a role } \\
\text { model }\end{array}$ & 4.0 & 5 & 3.5 \\
\hline
\end{tabular}

The previous discussion about the "Enablers" supported the first four hypothesis of this research that linked the first four enablers of the research model which are "leadership", "strategy and planning", "partnership and resources", and "HRM" by positive relationships with the "processes and change management". As we discussed above the weaknesses in the 
leadership in regard to motivate and support the people in the organization in addition to the weakness of the HRM and lack of developing and implementing partnership relations in general and with the citizens/customers in particular, caused shortage of HR skills that required more attention to the importance of the staff training and development and developed requirement system.

"The presented results reflect partly the status of the organizations; they may give more clear idea about other fields like technology, external environment, quality...so on. So we have to go more in depth in our analysis and assessment, because the purpose is to implement a model or models that we can adapt to our Saudi organizations into the level of European models, and to have in mind that the competitors are and will be international but not only in local area, this oblige us to have a strong model to resist to this competition, and to emerge in foreign and international markets"(one of the HR specialist).

Moreover, another one of the specialists pointed out the importance of the training to develop the Saudi employee skills "We assume that this partnership between Saudi and international organizations would encourage the world corporations to share the cost of training Saudis and preparing them for employment in the private sector and to finance programs and projects which aim to achieve "Saudization". This is a valuable comment to have a win-win situation between Saudi and international organization to help elevate the skills and competencies of the Saudi HR and reduce the unemployment rate in this country. 
According to the previous discussion related to the HRM, the following are some tools and techniques to develop more productive and involved HR within an organization:

- Supporting employees to help them attain their plans and objectives in support of organizational objectives is a key factor in HR development.

- Encouraging and supporting employees to make suggestions for innovation and improvement and to be proactive in their daily work.

- Stimulating and financing training and improvement activities. Giving feedback and discussing performance with employees.

- Recognizing and rewarding the efforts of teams and individuals.

- Addressing individual needs and situations of employee adequately.

On the other hand, we should also consider the areas of strengths in the enablers so the organizations can be proud of this high achievement and encourage the causes that contributed to this high score. The strategic \& planning scored 4.29 as an overall average for both sectors, which is considered very high score and definitely is considered as area of strength. This issue was addressed by an HR specialist "Leadership and Strategic Planning seem to be on the right track. However, the other parameters (i.e. HR Management, Partnership, and P\&CM) may need to be explored in more details".

This observation from the HR specialist reflects the honest opinion about the real status of the Saudi organizations. They are very strong when it comes to "Leadership" and "Strategic Planning". Based on the second part 
of this comment, we explored the parameters mentioned in the comment in more details.

\subsection{Discussions and Analysis of the "Results"}

Since all "Results " criteria for the chosen Saudi organizations in the two sectors that are represented in criteria 6 to 9 are above 3.0 (see table 3 ), that means the following conclusion for the four results are:

1. Results show modest progress.

2. We can calculate the percentage of each result based on how far it is from the score of 4.0:

- Customer, represents $3.8 / 5.0=76 \%$ which indicates that substantial progress are achieved and to some extent we can say positive comparisons to own targets are made in relation to the satisfaction of the organization's internal and external customers.

One of the specialist suggested that "for industrial organizations it needs to be reviewed and reinforced by other fields or criteria that all of them should respond to customer exigency \& satisfaction, continuous improvement, innovation and also control $\&$ audit organizations". This comment is very important as the customer should be the center or the core of the all planning within any organization, including the HR development. In order to have a better customer service and satisfaction, which is the result or the real outcome for any organization, the organization needs to have a well developed HR within its firs.

- Employees: represents 3.245/5.0 $=64.9$ which indicates that the organizations started to achieve good progress and to some extent 
positive comparisons to own targets are made in relation to the satisfaction of the organization's people.

- Society: represents $3.875 / 5.0=77.5 \%$ which indicates that substantial progress are achieved and positive comparisons to own targets are made in satisfying the needs and the expectations of the local, national, and international community at large. This includes the perception of the organization's approach to quality of life, the environment and the preservation of global resources, and the organization's own internal measures of effectiveness. It includes its relations with authorities and bodies, which affect and regulate its business.

- Performance : represents $3.775 / 5.0=75.5 \%$ this also indicates that substantial progress are achieved and positive comparisons to own targets are made in relation to the organization's mandate and specified objectives and in satisfying the needs and expectations of everyone with a financial interest or other stake in the organization.

Based on the above analysis, it is obvious the "Employees " scored the lowest among the four results. This is the second conclusion that the Saudi organizations have the least amount of attention and considerations towards the human resources and their people. This result criterion shows what the organization achieves in relation to the satisfaction of its people. Therefore, this criterion should address the satisfaction of all the people in the organization and should link to the human resource management criterion.

The following table 7 represents the "Employees" criterion with its two sub-criterion. The first one "results of people satisfaction and motivation measurement" scored the lowest (3.0) in the industrial organization. This indicates that the overall of people satisfaction including the employees' 
image of the organization and its mission, the working environment, the organization's management and management systems, career development, the development of personal skills and the products and services the organization provides, this result shows substantial progress, but still needs a lot to do to improve their satisfaction, their performance, the development of skills, their motivation and their involvement in the organization.

\begin{tabular}{|c|l|c|c|c|}
\hline \multicolumn{5}{|c|}{ Table 7 : The Descriptive Analysis of The Leadership Criterion } \\
\hline No. & \multicolumn{1}{|c|}{ Sub-Criterion } & $\begin{array}{c}\text { Banking } \\
\text { Sector }\end{array}$ & $\begin{array}{c}\text { Industrial } \\
\text { Sector }\end{array}$ & Average \\
\hline 7.1 & $\begin{array}{l}\text { Results of people satisfaction and } \\
\text { motivation measurements }\end{array}$ & 3.6 & 3 & 3.3 \\
\hline 7.2 & Indicators of people results & 3.6 & 3.5 & 3.55 \\
\hline
\end{tabular}

This previous kind of weakness should be dealt with and given more attention from the upper management in the Saudi corporation to improve the overall performance results in general and the HR in particular.

To get more in depth looking for areas of weaknesses in the results criteria, the following table will present the other three criterion of the "Results" to be discussed in details.

Table 2: Descriptive Analysis of The Industrial Sector

\begin{tabular}{|c|c|l|c|c|c|}
\hline Criteria & \multicolumn{2}{|c|}{ Sub-Criteria } & $\begin{array}{c}\text { No. of } \\
\text { items }\end{array}$ & score & Average \\
\hline \multirow{3}{*}{ Customer } & 6.1 & $\begin{array}{l}\text { Results of customer/citizen } \\
\text { satisfaction measurements }\end{array}$ & 3.9 & 3.5 & 3.7 \\
\cline { 2 - 6 } & 6.2 & $\begin{array}{l}\text { Indicators of customer/citizen- } \\
\text { oriented measurements }\end{array}$ & 3.8 & 4 & 3.9 \\
\hline
\end{tabular}




\begin{tabular}{|l|c|l|c|c|c|}
\hline Society & $\mathbf{8 . 1}$ & Results of societal performance & 3.6 & 4 & 3.8 \\
\hline & 8.2 & $\begin{array}{l}\text { Results of environmental } \\
\text { performance }\end{array}$ & 3.9 & 4 & 3.95 \\
\hline \multirow{2}{*}{ performance } & 9.1 & Goal achievement & 3.8 & 3.7 & 3.75 \\
\cline { 2 - 6 } & 9.2 & Financial performance & 3.65 & 4 & 3.825 \\
\hline
\end{tabular}

Since we addressed the weaknesses in the "Results", we should also capitalize on the best "Results" as well. The highest score in the results was given to the "Society" which reached $77.5 \%$ in satisfying the needs and the expectations of the local, national, and international community at large. The causes leading to this good score should be emphasized and encouraged more to reach even to higher score.

It is equally important to notice also that the scores of the "Performance", including its components "Goal achievement" and "Financial performance", were relatively high, $75 \%$ and $76.5 \%$ respectively. This is a clear indication that the organizations in these categories are more focused and concerned about the performance as a result of their high standards of operations in this critical parameter. As a conclusion, this high achievement should be emphasized and encouraged.

Based on the previous discussion about the "Results" criteria, the last three hypotheses were supported as the processes of the human resource management is positively related to the customer and employees satisfaction, and to the organization performance. Here, as we mentioned earlier the HR considered as the heart of any organization therefore, it is affecting the outcome. Consequently, based on the research results and the modest progress of the HR planning and activities such as training and 
development in addition to the organization development in terms of the willingness of the employees to be more involved in their employing organizations, and more dedicated to delivering services with a high level of quality. Thus the overall results of the employees and customers satisfaction achieved substantial progress.

\section{Obstacles}

During this phase of the research projects, we faced several challenges that have been expected before we started this research project. These challenges are mainly focused in the responses of the individuals whom we requested to participate in providing the necessary information included in the questionnaire. Since those individuals are the heads of HR Departments or other Departments, it is apparent that they are busy doing their daily workloads. In some cases, we have to contact some persons several times to get partial information in each contact either by phone, fax, e-mail, and visits. Most of them understood the value of this research and were very much cooperative but they could not spend too much time responding to the questionnaires.

The other challenge has been the market segmentation and the random selection of the samples to participate in this research project and provide the required information in the questionnaire. It took us quite some time to assess and evaluate the different market sectors and try to understand the most influential sectors in the Saudi economy in general. Since we cannot cover all private sectors for obvious practical reasons, we had to perform initial evaluation and analyses among all private sectors. The conclusion we reached to, was satisfactory to serve the purpose of this research project. At the end, we concluded that the banking and industrial sectors 
are the most influential sectors in driving the economy. Consequently, studying the HR development in these two sectors will have great impact in the Saudi economy in general and the private sector in particular.

\section{Conclusions and Recommendations}

Joining the WTO means that Saudi organizations will face great challenges to improve the performance of their organizations. The greatest challenges of all is work practices that limit employee performance levels compared with those in Western international companies. Accordingly, the objective of this research project is to conduct a study and analysis on samples of Saudi organizations using the HR Model that has been developed specifically for this project.

Since it is not practical to perform this study on several economic sectors in the Saudi organizations, the researcher has selected the two most influential sectors; namely, banking and industrial sectors. As a result, a "methodology" has been developed that can be considered as the road map for the Saudi organizations to improve the quality of services they provide through the HR development. The same methodology can be used as well for future works.

However, one of the HR specialist addressed the following comment "the data seems to be well organized, however, one industrial company and two banks are not representative of the Saudi market. It is suggested that more industrial, commercial and financial companies are included in the project". In fact, the main objective of this research is to develop a "methodology" for the research and analysis that can be considered as the road map for future works. Therefore, we recommend further research could be taken to include more sectors and larger numbers of organizations. 
Another point was pointed out by one of the specialists is the following: "The "Model" developed in this research paper is targeted for medium and large size companies. Please note that small and medium size companies (SME's) in Saudi Arabia represent almost 90 percent of total enterprises in the Saudi market. In addition, we suggest that you also include family companies in your study. According to Davis, Pitts and Cormier, family companies constitute about $90 \%$ of the trading activities in the Gulf region. The percentage in the other regions of the world is between $65 \%$ and $80 \%$. This kind of companies, in fact, is increasing in Saudi Arabia. The total number of these companies had reached 621.4 thousand companies according to the Saudi Arabian Monetary Agency (SAMA) statistics. The family companies in Saudi Arabia constitute 95\% of the total companies in the country. Actually, 45 of the 100 largest Saudi companies are family business including Al-Zamil Group, AlRachid Group, Al-Rajhi Group, National Commercial Bank and Ben Ladin Group. As your study benchmarks the Saudi market with the international, we recommend that you include the family factor in your study."

We agree that the SMEs represent $90 \%$ of the Saudi market, yet the small organizations may not be interested in HR development due to the cost factor and they do not sense any competition that may threaten their business from international foreign organizations. Therefore, the focus in the Model as well as this research is on the medium/large organization for the reason mentioned above. 
In this research project, we have done the data gathering, analysis, and discussions on two banks are selected and one industrial organization as a "case study". The conclusion we reached was satisfactory to serve the purpose of this research project. At the end, we concluded that the banking and industrial sectors are the most influential sectors in driving the economy. Consequently, studying the HR development in these two sectors will have great impact in the Saudi economy in general and the private sector in particular. We suggested that other research projects in the future can include more sectors and larger numbers or organizations.

Based on the Model we applied in this research, with its nine criteria, we concluded that the Saudi organizations have several points of strengths, which they should capitalize on, and other points of weakness, that need to be focused on for improvements. Out of the nine criteria, there are five "enablers " and four "results".

For the enablers, and based on the data gathered and analyzed, the Saudi organizations are very strong when it comes to "Leadership" and "Strategic Planning". Yet, they are low in the scores of the HR and employees.

For the results, the best result criteria "Society" that scored $77.5 \%$ followed by "Performance" that scored $75.5 \%$. Based on the above analyses, it is obvious the "Employees" scored the lowest among the four results. This kind of weakness should be dealt with and given more attention from the upper management in the Saudi corporation to improve the overall performance results in general and the HR in particular.

Once the HR structure is developed based on the world class standards, the accession to the World Trade Organization (WTO) will definitely be considered as an excellent opportunity to the Saudi corporations, not a 
threat. We recommend that further studies to be done on other Saudi economic sectors. Gathering larger amount of data and results will definitely help to draw an overall and complete picture of the Saudi economy. We recommend that Saudi organizations should take the HR development issue very seriously to cope with the globalization trend. 


\section{References}

- Baldwin JR., Chandler, W., and Papailiadis, T. (1994), "Strategies for Success: A Profile of Growing Small and Medium-sized Enterprises in Canada". Catalogue 61-523-RPE, Ottawa: Statistics Canada.

- Barsade, S.G. (2002), "The ripple effect: emotional contagion and its influence on group behavior", Administrative Science Quarterly. Vol. 47/4, pp. 644-675.

- Bou-Llusar, J., Escrig-Tena, A., Roca-Puig, V. and Beltran-Martin, I. (2008), "An empirical assessment of the EFQM Excellence Model: Evaluation as a TQM framework relative to the MBNQA Model", Journal of Operations Management,

- Byars, L. and Rue, L. (2006), Human resource management. $8^{\text {th }}$ ed., New York: McGraw-Hill

- CAP Resource Centre at the European Institute of Public Administration (2005), "Publication study on the use of the Common Assessment Framework in European Public Administrations", 2nd European CAP event, Luxembourg, 1-2 June 2005.

- CAP Resource Centre Brochure (2006), "The Common Assessment Framework (CAP): Improving an organization through self assessment", European Institute of Public Administration. V08.doc.

- Calvo-Mora, A., Leal, A., and Roldan, J. (2006), "Using enablers of the EFQM model to manage institutions of higher education", Quality Assurance in Education. Vol. 14/2, pp. 99 - 122. 
- Camison, C. (1996), "Total quality management in hospitality: an application of the EFQM model", Tourism Management. Vol. 17/3, pp. 191-201.

- Process on business performance", European Journal of Operational Research. Vol. 146/3, pp. 580-595

- The Common Assessment Framework CAF (2002), "Improving an organization through self-assessment", The Second Quality Conference for Public Administrations in the EU. Copenhagen, Denmark, 2-4 October.

- Tichy, N., Fombrun, C., and Devanna, M. (1981), "Strategic human resource management", Division of Research, The University of Michigan.

- Van der Wiele, A., Williams, R., Dale B., and Carter, G. (1996), "Quality management self-assessment: An examination in European business", Journal of General Management. Vol. 2211, pp. 48-67.

- Van der Wiele, T. and Brown, A. (1999), "Self-assessment practices in Europe and Australia", International Journal of Quality \& Reliability Management Vol. 16/3, pp. 238-251.

- Venkateshwara, B. (2006), "A comparative study of Human Resource Management practices and advanced technology adoption of SMEs with and without...", Business Personnel Management,

- Vijande, M. (2007), "TQM and firms performance: An EFQM excellence model research based survey", International Journal of Business Science and Applied Management Vol. 2/2 
- Wisner J. and Eakins, S. (1994), "A performance assessment of the US Baldrige quality award winners", International Journal of Quality \& Reliability Management. Vol. 11/ 2, pp. 8-25.

- Westerveld, E. (2003), "The Project Excellence Model: linking success criteria and critical success factors", International Journal of Project Management, Vol. 21, pp. 411-418.

- Yeung, A., Brockbank, W., and Ulrich, D. (1994), "Lower Cost, Higher Value: HR Function in Transformation," Human Resource Planning Journal. Vol. 17/3.

- Yeung, A. and Brockbank, W. (1995), "Reengineering HR Through Information Technology," Human Resource Planning Journal. 1995, Vol. 18/2.

- Yeung, A. (1996), "Identifying and developing HR competencies for the future: keys to sustaining the transformation of HR functions ", Human Resource Planning.

- Yoon, M.H. and Suh, J., (2003), "Organizational citizenship behaviors and service quality as external effectiveness of contact employees", Journal of Business Research. Vol. 56/8, pp. 597-611.

- Zikmund, W. (1997), Business Research Methods. $5^{\text {th }}$ edition, USA: The Dryden Press -http://www.experiment-resources.com/case-study-researchdesign.html

- http://www.proveandimprove.org 